\title{
PROPERTIES OF THE $\mathrm{ZrO}_{2} \mathrm{MgO} / \mathrm{MgZrO}_{3} \mathrm{NiCr} / \mathrm{NiCr}$ TRIPLE- LAYER THERMAL BARRIER COATING DEPOSITED BY THE ATMOSPHERIC PLASMA SPRAY PROCESS
}

\author{
Mihailo R. Mrdak \\ Research and Development Center IMTEL Communications a.d., \\ Belgrade, Republic of Serbia \\ e-mail: miki@insimtel.com, \\ ORCID iD: (i)http://orcid.org/0000-0003-3983-1605
}

DOI: $10.5937 /$ vojtehg64-9612

FIELD: Chemical Technology

ARTICLE TYPE: Original Scientific Paper

ARTICLE LANGUAGE: English

\section{Summary:}

This paper presents the results of the examinations of TBC $\mathrm{ZrO}_{2} \mathrm{MgO} / \mathrm{MgZrO}_{3} \mathrm{NiCr} / \mathrm{NiCr}$ thermal barrier layers deposited by the plasma spray process at the atmospheric pressure on substrates of $\mathrm{Al}$ alloys. In order to obtain the structural and mechanical properties of layers, which will provide a good heat and abrasion protection of the tail elevators of aircraft J-22 when firing "Lightning" and "Thunder" rockets, the deposition of three powder types was performed on $0.6 \mathrm{~mm}$ thick Al alloy substrates. This study describes a procedure of using triple-layer TBC coatings as a good combination among many available ones, which gives a good compromise between thermal protection and resistance to abrasion for protecting aircraft tail elevators. The study is mainly based on the experimental approach. The evaluation of the mechanical properties of layers was done by the examination of microhardness by method $\mathrm{HV}_{0.3}$ and bond strength on the tensile machine. The structure of layers was examined by the method of light microscopy while the surface of $\mathrm{ZrO}_{2} \mathrm{MgO}$ ceramic layers was examined by the method of scanning electron microscopy (SEM).The thermal protection of TBC layers and resistance to abrasion were tested in the tunnel of the MilitaryTechnical Institute, Zarkovo. The obtained characteristics of the surface layers and the rocket firing simulations have proven the triple-layer system of TBC coatings reliable.

Key words: substrates, protective, property, layers, coatings, barriers, alloys.

ACKNOWLEDGMENT: The author is thankful for the financial support from the Ministry of Education and Science of the Republic of Serbia (national projects OI 174004, TR 34016). 


\section{Introduction}

TBC - thermal barrier plasma spray coatings are widely used to protect parts of turbo jet engines and other engine parts exposed to high temperatures, oxidation, corrosion and erosion of gas particles. Plasmadeposited TBC ceramic coatings are a good solution for the thermal protection of diesel engine parts such as pistons, valves, etc. (Çelik, et al., 1997, pp.361-365), (Demirkiran, Avci, 1999, pp.292-295), (Miyamoto, et al., 1999, p.100). Oxide $\mathrm{ZrO}_{2}$ was selected because of its high strength and fracture toughness compared to other oxides, and physical characteristics such as a thermal conductivity of $\lambda \approx 1.7 \mathrm{~W} / \mathrm{mK}$, a coefficient of thermal expansion of $\alpha \approx 9 \times 10^{-6} 1 / \mathrm{K}$ and a melting point of $2710^{\circ} \mathrm{C}$ (Boutz, et al., 1994, pp.89-102), (Chevalier, et al., 2009, pp.19011920). The polymorphism of pure $\mathrm{ZrO}_{2}$ is an important feature (Johner, Schweitzer, 1984, pp.301-315). At the atmospheric pressure, there are three crystallographic phases: the monoclinic, the tetragonal and the cubic one. When alternating heating and cooling, the thermal fatigue of the $\mathrm{ZrO}_{2}$ material occurs due to the volume changes caused by the phase transformation. As a result of the reversible transformation of the monoclinic phase into the tetragonal one, the occurrence of microcracks spreading and converting into macro crevices was observed in the temperature range of $950^{\circ} \mathrm{C}-1170^{\circ} \mathrm{C}$ (Garvie, et al., 1975, pp.703-704), (Garvie, 1970, pp.117-166). For this reason, pure $\mathrm{ZrO}_{2}$ is not suitable for the preparation of the TBC coating. In order to reduce the effect of the tetragonal transformation into the monoclinic one, other oxides such as $\mathrm{MgO}, \mathrm{CaO}, \mathrm{Y}_{2} \mathrm{O}_{3}, \mathrm{CeO}_{2}, \mathrm{HfO}_{2}$, and $\mathrm{In}_{2} \mathrm{O}_{3}$ are added to pure $\mathrm{ZrO}_{2}$. These additives stabilize the ceramic layer partially or in full by forming a cubic structure stable from the room temperature up to more than $2000^{\circ} \mathrm{C} . \mathrm{ZrO}_{2}$ with addition of magnesium oxide $\mathrm{MgO}$ is often used as a TBC due to its high coefficient of linear expansion that is $11 \times 10^{-6} 1 / \mathrm{K}$, a coefficient of thermal conductivity of $1.5 \mathrm{~W} / \mathrm{mK}$, high resistance to thermal cycles, resistance to corrosion, and easy preparation of the coating by plasma spray spraying. When the TBC is subjected to elevated temperatures, this induces mechanical degradation that involves the stratification and cracking of ceramics as a result of the factors such as stresses due to thermal expansion conflicts related to the changes in the microstructure because of thermal cycles. TBC coatings consist of at least two layers. The outer, generally thicker layer is made of a ceramic material or a mixture of ceramics and fire-resistant metals, the primary purpose of which is to provide thermal insulation and resistance to thermal shocks. The material of the ceramic layer which is in a direct contact with the working fluid, has a drop of temperature per cross section even to $400-500^{\circ} \mathrm{C}$ (Mrdak, et al., 2013, pp.559-567), (Mrdak, et al., 2015, pp.337-343). That 
layer should also have resistance to erosive effects and good bonding with the substrate material. The inner, thinner layer provides protection from the oxidative degradation of the base material, but also provides a good bond between the base metal and the outer ceramic layer. In order to reduce stresses, triple-layer systems of TBC coatings are often produced; they consist of the bonding $\mathrm{NI} 20 \% \mathrm{Cr}$ layer, the transitional $\mathrm{MgZrO}_{3} 35 \% \mathrm{NiCr}$ cermet inter-layer and the top $\mathrm{ZrO}_{2} 24 \% \mathrm{MgO}$ ceramic layer. This study describes a method of using the triple-layer TBC coatings as a selection of a good combination among many available options, which provides a good compromise between the thermal protection and the resistance to erosion of the Al alloy substrate for protecting the tail elevators of aircraft J-22. The study is mainly based on the experimental approach. The properties of the deposited materials are generally functions of their microstructures. According to previous studies, plasma deposited ceramic deposits show a lamellar structure with limited inter - lamellar bonding ( $\mathrm{Li}$, Ohmori, 2002, pp.365-374) (Mrdak, et al., 2013, pp.559-567). Because of this, micro pores are present in the deposit as volume errors.

This paper presents the examination of a $\mathrm{ZrO}_{2} \mathrm{MgO} / \mathrm{MgZrO}_{3} \mathrm{NiCr} / \mathrm{NiCr}$ triple-layer system of TBC coatings deposited by the atmospheric plasma spraying (APS) process on the substrates of Al alloys, which serve as the thermal abrasive barriers of the tail elevators of aircraft J-22. The aim of the study was to produce the TBC coatings of such structural and mechanical properties of the layers which will provide a good heat and abrasion protection on the aircraft tail elevators when firing "Lightning" and "Thunder" rockets. The microhardness and bond tensile strength of the triple system of TBC coatings and layer microstructures were examined. The obtained characteristics of the TBC layers and rocket firing simulations have proven the triple-layer system of TBC coatings reliable.

\section{Materials and experimental details}

The material on which layers of the $\mathrm{ZrO}_{2} \mathrm{MgO} / \mathrm{MgZrO}{ }_{3} \mathrm{NiCr} / \mathrm{NiCr}$ triple-layer TBC coating were deposited was aluminum alloy ENAWAlMg1(C)(ENAW-5005). For the production of the top ceramic coating layers, the $\mathrm{ZrO}_{2} 24 \% \mathrm{MgO}$ powder of the Sulzer Metco company, labelled Metco $210 \mathrm{NS}-1$, was used. The powder is produced by the method of casting into blocks and subsequent grinding of these blocks to obtain a specific granularity. The melting point of powder is $2140^{\circ} \mathrm{C}$. The powder

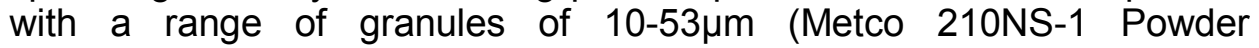
Magnesium Zirconate, 2000.Sulzer Metco.Technical Bulletin 10-289) was used for the experiment. Figure 1 shows a (SEM) scanning electron photomicrography of the morphology of $\mathrm{ZrO}_{2} 24 \% \mathrm{MgO}$ powder particles. The powder particles are of an irregular angular shape. 


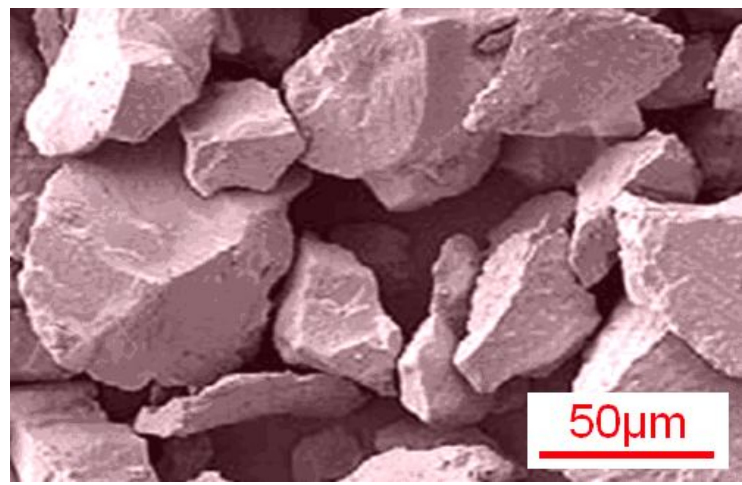

Figure 1 - (SEM) Scanning electron micrography of $\mathrm{ZrO}_{2} 24 \% \mathrm{MgO}$ powder particles Slika 1 - (SEM) Skening elektronska mikrografija čestica praha $\mathrm{ZrO}_{2} 24 \% \mathrm{MgO}$ Puc. 1 - (SEM) Электронная микрографрия частиц порошка $\mathrm{ZrO}_{2} 24 \% \mathrm{MgO}$

For the production of inter-layer TBC coatings, $\mathrm{MgZrO}_{3} 35 \% \mathrm{NiCr}$ cermet powder of the Sulzer Metco company, labelled Metco 303NS - 1, was used. The powder is a mechanical mixture of $\mathrm{ZrO}_{2} \mathrm{MgO}$ powder and $\mathrm{NiCr}$ in relation $35 \%(80 \mathrm{Ni} 20 \% \mathrm{Cr})+65 \%\left(\mathrm{ZrO}_{2} 24 \% \mathrm{MgO}\right)$. Powder with a range of granules of 11-90 $\mu \mathrm{m}$ (Material Product Data Sheet, 2012.Metco 303NS-1 Magnesium Zirconate-Nickel Chromium Cermet Blends.Sulzer Metco DSMTS- 0070.0) was used for the experiment. For the production of the lower bonding layer, the powder type labelled Metco 43F-NS (an alloy of nickel and chromium NI20\%Cr) was used. The melting point of the powder is $1400^{\circ} \mathrm{C}$. The powder with a range of granules of $10-63 \mu \mathrm{m}$ (Material Product Data Sheet, 2012. Metco 43F-NS Nickel-20\% Chromium Powders. Sulzer Metco.DSMTS-0109.0) was used for the experiment.

Testing the mechanical properties of the $\mathrm{ZrO}_{2} \mathrm{MgO} / \mathrm{MgZrO}{ }_{3} \mathrm{NiCr} / \mathrm{NiCr}$ TBC coating was done according to the Pratt \& Whitney standard (Turbojet Engine - Standard Practices Manual (PN 582005), 2002. Pratt \& Whitney, East Hartford, USA). The bases with deposited coating layers for the microhardness testing and the evaluation of microstructure in a deposited condition are made of ENAW-AIMg1(C)(ENAW 5005) aluminum alloy with the dimensions $70 \times 20 \times 1.5 \mathrm{~mm}$. The bases for testing bond strength are also made of ENAW-AIMg1(C)(ENAW-5005) aluminum alloy with the dimensions $\varnothing 25 \times 50 \mathrm{~mm}$. The investigation of the microhardness of the layers was done by the method $\mathrm{HV}_{0.3}$ and the bond strength was tested on a tensile machine. Microhardness measurements were performed in the direction along the lamellas. Five readings of microhardness values of the layers were performed in the middle and at the ends of the samples while two extreme values were rejected. Out of three remaining values, minimum and maximum values are shown. The 
bond strength testing was done at room temperature with a speed of tensile testing of $1 \mathrm{~cm} / 60 \mathrm{~s}$. The bond strength testing was performed for each individual coating 43F-NS (80Ni20\% Cr), 303NS-1 $\left(\mathrm{MgZrO}_{3} 35 \% \mathrm{NiCr}\right)$ and $210 \mathrm{NS}-1\left(\mathrm{ZrO}_{2} 24 \% \mathrm{MgO}\right)$. The bond strength of the $\mathrm{ZrO}_{2} \mathrm{MgO} / \mathrm{MgZrO}_{3} \mathrm{NiCr} / \mathrm{NiCr}$ triple system of $\mathrm{TBC}$ coatings was tested as well. Five test pieces were examined for all types of coatings, out of which two extreme values were rejected. The average bond strength value is shown for the three remaining values. The morphology of the $\mathrm{ZrO}_{2} 24 \% \mathrm{MgO}$ powder particles and that of the deposited coating surface were determined by using scanning electron microscopy (SEM). The microstructure of the deposited layers was examined on the optical microscope (OM). The analysis of the share of micro pores in the coating layers was done on five photos at the 200X magnification. Over tracing paper, micro pores were labelled and shaded and their total area was counted in relation to the total surface of the micrographs. This paper presents the average value of the shares of micro pores in the TBC coating layers.

The deposition of powders was done with the atmospheric plasma spray system by the Plasmadyne company and the SG-100 plasma gun with controlled plasma spray parameters. The SG-100 plasma gun consisted of the cathode type K 1083A-129, the anode type A 1083-165 and the gas injector type GI 1083-113. Ar as an arched gas was used in combination with $\mathrm{He}$ and the power of supply of $40 \mathrm{KW}$. The plasma spray parameters of the deposition powders are shown in Table 1. Before the depositing process, the surface of the test samples and the surface of the substrate of the thermal abrasive barrier for the aircraft tail elevators were not roughened, due to the small thickness of the substrate of $0.6 \mathrm{~mm}$. The bonding layers were deposited with a thickness of $60-$ $80 \mu \mathrm{m}$, the cermet layers with a thickness of $40-60 \mu \mathrm{m}$ and the top ceramic layer with a thickness of $280-300 \mu \mathrm{m}$.

Table - 1 Parameters of the deposition of powders

Tabela 1 - Parametri depozicije prahova

Таблица 1 - Параметры напыления порошка

\begin{tabular}{|l|c|c|c|}
\hline Parameters & 43F-NS & $303 \mathrm{NS}-1$ & $210 \mathrm{NS}-1$ \\
\hline Electric Current, I (A) & 700 & 900 & 900 \\
\hline Arc voltage, U (V) & 30 & 43 & 43 \\
\hline Primary plasma gas, I/min & 50 & 50 & 50 \\
\hline $\begin{array}{l}\text { Secondary plasma gas, } \\
\text { I/min }\end{array}$ & 12 & 12 & 12 \\
\hline Carrier gas powder, I/min & 7 & 7 & 7 \\
\hline Powder feed rate, g/min & 50 & 50 & 50 \\
\hline Distance of plasma guns, $\mathrm{mm}$ & 90 & 100 & 100 \\
\hline
\end{tabular}




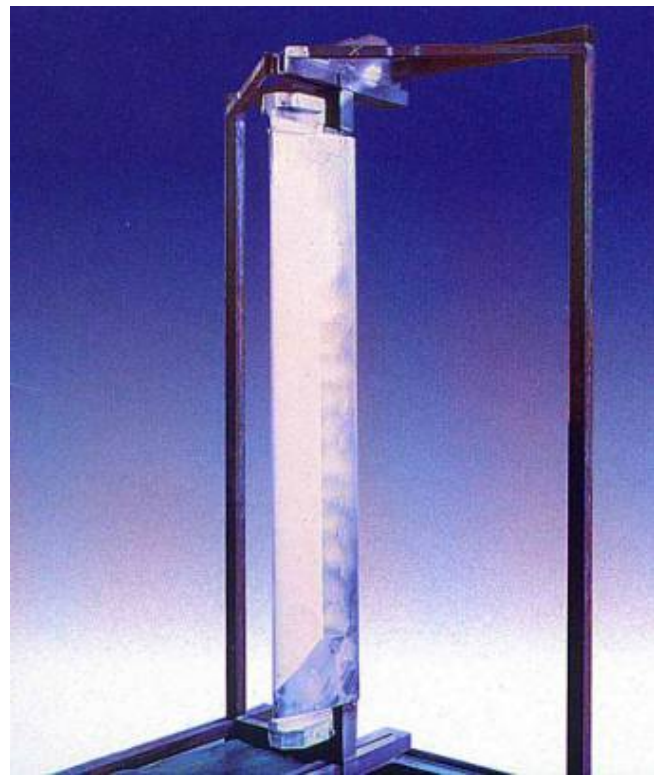

Figure 2 - Section of the edge of the aircraft rear wing with a TBC coating Slika 2 - Sekcija ivice zadnjeg krila aviona sa TBC prevlakom Puc. 2 - Часть заднего крыла самолета с ТВС покрытием

Figure 2 shows one section of the edge of the aircraft tail elevators with a deposited TBC coating.

\section{Results and discussion}

The values of microhardness and bond strength of TBC coating systems are shown in Figures 3 and 4 . The metal bonding coating 43FNS (NI20\%Cr) had the lowest values of microhardness of $238-254 \mathrm{HV}_{0.3}$, which are within the limits of values prescribed by the powder manufacturer and by the standard (Material Product Data Sheet, 2012. Metco 43F-NS Nickel-20\% Chromium Powders, Sulzer Metco. DSMTS0109.0) (Turbojet Engine-Standard Practices Manual (PN 582005) 2002.Pratt \& Whitney, East Hartford, USA). The measured values of the microhardness of the bonding layers indicate that the share of micro pores is within the prescribed limits, which was confirmed by the analysis of the shares of micro pores. Due to ceramics content, the layers of the cermet coating $303 \mathrm{NS}-1 \quad\left(\mathrm{MgZrO}_{3} 35 \% \mathrm{NiCr}\right)$ had higher values of microhardness, in a range of $293-330 \mathrm{HV}_{0.3}$ and in accordance with the Pratt \& Whitney standard(Turbojet Engine-Standard Practices Manual (PN 582005) 2002. Pratt \& Whitney, East Hartford, USA). 
The layers of the ceramic coating Metco $210 \mathrm{NS}-1\left(\mathrm{ZrO}_{2} 24 \% \mathrm{MgO}\right)$ had the highest microhardness values of $478-519 \mathrm{HV}_{0.3}$ that are characteristic for this type of the coating. These layers had the highest share of micro pores because ceramic particles create a weaker interlamellar contact in comparison to metal particles. Figure 3 shows the minimum and maximum values of the microhardness of TBC coatings.

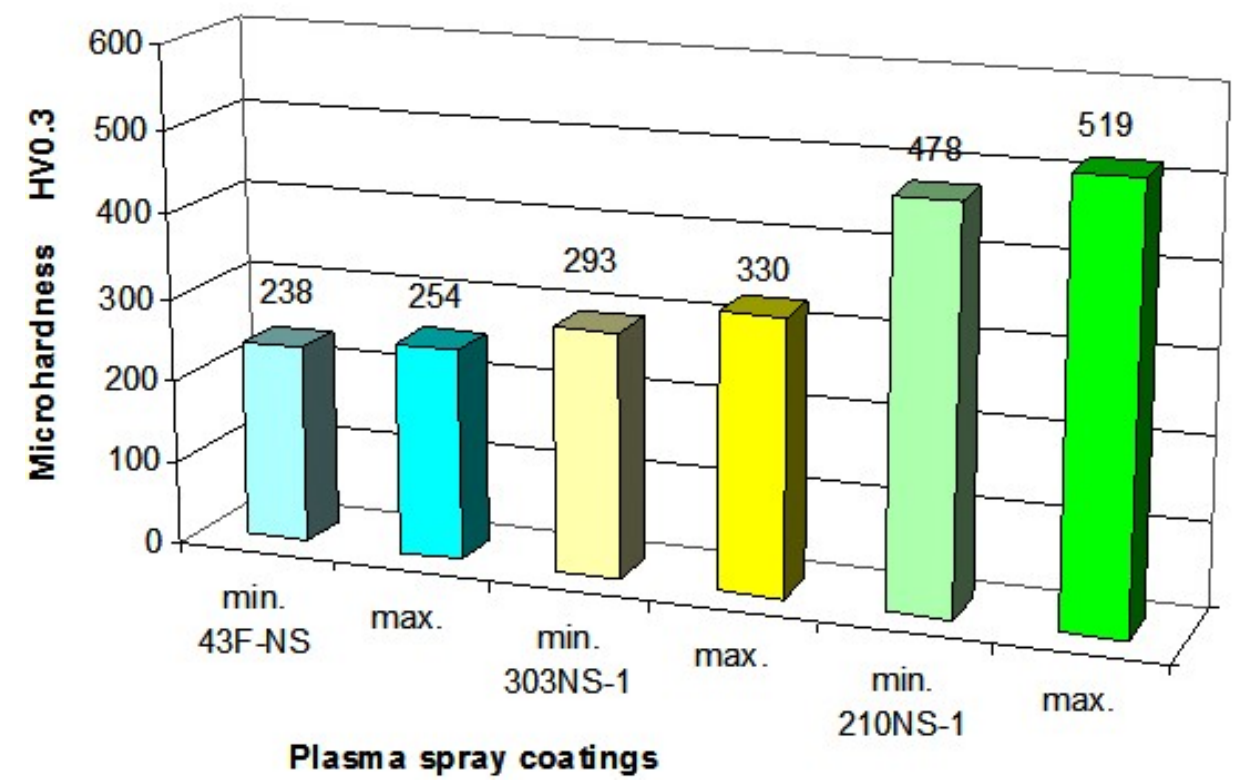

Figure 3 - Microhardness of $\mathrm{ZrO}_{2} 24 \% \mathrm{MgO}, \mathrm{MgZrO}_{3} 35 \% \mathrm{NiCr}$ and $\mathrm{Ni20} \% \mathrm{Cr}$ coatings Slika 3 - Mikrotvrdoća $\mathrm{ZrO}_{2} 24 \% \mathrm{MgO}, \mathrm{MgZrO}_{3} 35 \% \mathrm{NiCr}$ i Ni20\%Cr prevlaka

Puc. 3 - Микротвердость $\mathrm{ZrO}_{2} 24 \% \mathrm{MgO}, \mathrm{MgZrO}_{3} 35 \% \mathrm{NiCr}$ і Ni20\% Cr покрытия

The tensile bond strength of coatings was directly related to the powder type. The highest bond strength values of $31 \mathrm{MPa}$ were found in the metal bonding layers of $43 \mathrm{~F}-\mathrm{NS}(\mathrm{NI} 20 \% \mathrm{Cr})$ coating. The layers of cermet coating $303 \mathrm{NS}-1$ ( $\mathrm{MgZrO}_{3} 35 \% \mathrm{NiCr}$ ) had a tensile bond strength of $22 \mathrm{MPa}$, while a minimum value of $17 \mathrm{MPa}$ was found in the ceramic layers of Metco $210 \mathrm{NS}-1\left(\mathrm{ZrO}_{2} 24 \% \mathrm{MgO}\right)$. For all coatings, the bond strength values were good because the coatings were deposited on the non-roughened substrates of Al alloy which reduce the tensile bond strength in relation to roughened substrates based on $\mathrm{Fe}$ or $\mathrm{Ni}$ alloys.

The average tensile strength value of the $\mathrm{ZrO}_{2} \mathrm{MgO} / \mathrm{MgZrO}{ }_{3} \mathrm{NiCr} / \mathrm{NiCr}$ system of TBC coatings was $30 \mathrm{MPa}$. The TBC coating was destroyed at the substrate/coating interface, which was expected due to two different materials. The measured values of microhardness and tensile bond 
strength of the $\mathrm{ZrO}_{2} \mathrm{MgO} / \mathrm{MgZrO}_{3} \mathrm{NiCr} / \mathrm{NiCr}$ system of of $\mathrm{TBC}$ coatings were in correlation with the microstructure of deposited layers.

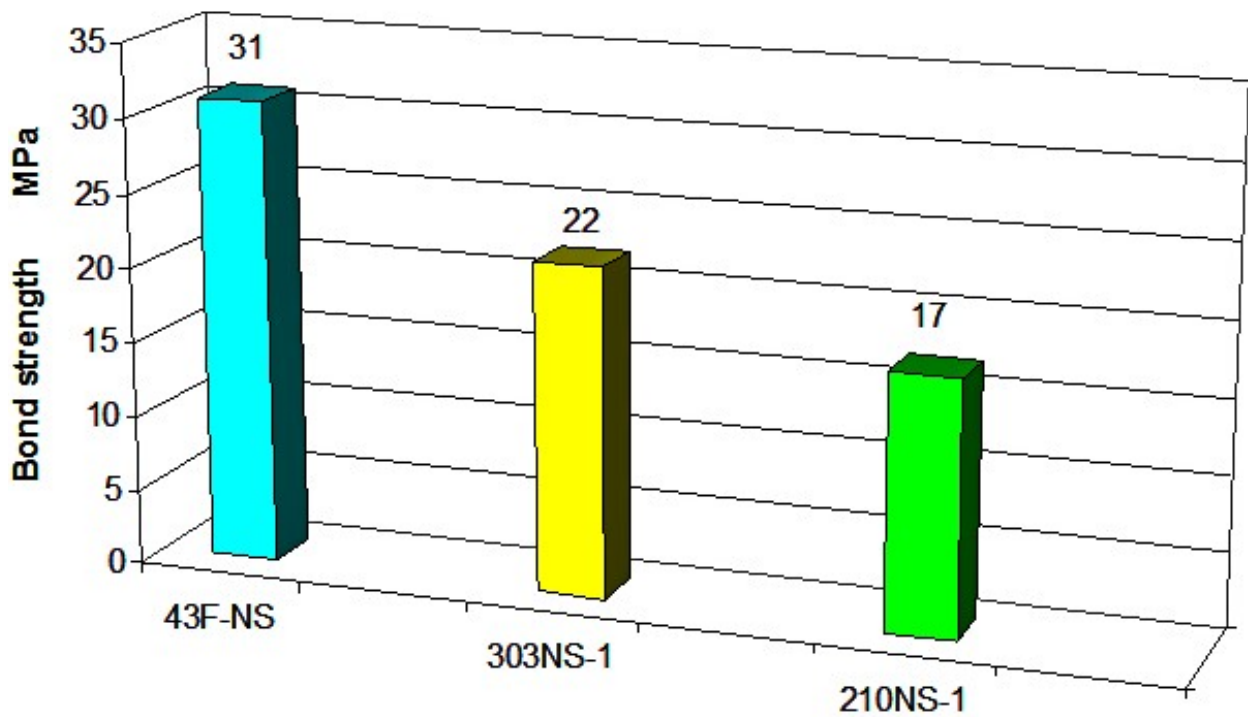

Plasma spray coatings

Figure 4 - Bond strength of $\mathrm{ZrO}_{2} 24 \% \mathrm{MgO}, \mathrm{MgZrO}_{3} 35 \% \mathrm{NiCr}$ and $\mathrm{Ni2} \% \mathrm{Cr}$ coatings Slika 4 - Čvrstoća spoja $\mathrm{ZrO}_{2} 24 \% \mathrm{MgO}, \mathrm{MgZrO}_{3} 35 \% \mathrm{NiCr}$ and $\mathrm{Ni} 20 \% \mathrm{Cr}$ prevlaka Puc. 4 - Микропрочность соединений $\mathrm{ZrO}_{2} 24 \% \mathrm{MgO}, \mathrm{MgZrO}_{3} 35 \% \mathrm{NiCr}$ and $\mathrm{Ni} 20 \% \mathrm{Cr}$ покрытия

Figures 5 and 6 shows the microstructure of the triple system of thermal barrier coatings $\mathrm{TBC}-\mathrm{ZrO}_{2} 24 \% \mathrm{MgO} / \mathrm{MgZrO}_{3} 35 \% \mathrm{NiCr} / \mathrm{Ni} 20 \% \mathrm{Cr}$. The photomicrographs clearly show the boundaries of the interface between the bonding coating layers and the substrate, the bonding coating and the cermet coatings, as well as between the cermet coatings and the ceramic coatings. The interface between the substrate and the bonding coating layers is very clean, which indicates a good bond between the coating layers with the substrate. At the interface between the substrate and the bonding coating layers there are no defects such as discontinuities of deposited layers, microcracks, macrocracks, coating peeling and separation from the substrate. Generally, the layers are uniformly deposited on the substrate. Along the following interfaces: the substrate / the bonding coatings, the bonding coatings / the cermet coatings and the cermet coatings / the ceramic coatings, there are no microcracks and macrocracks present. The bond between all layers is good. 


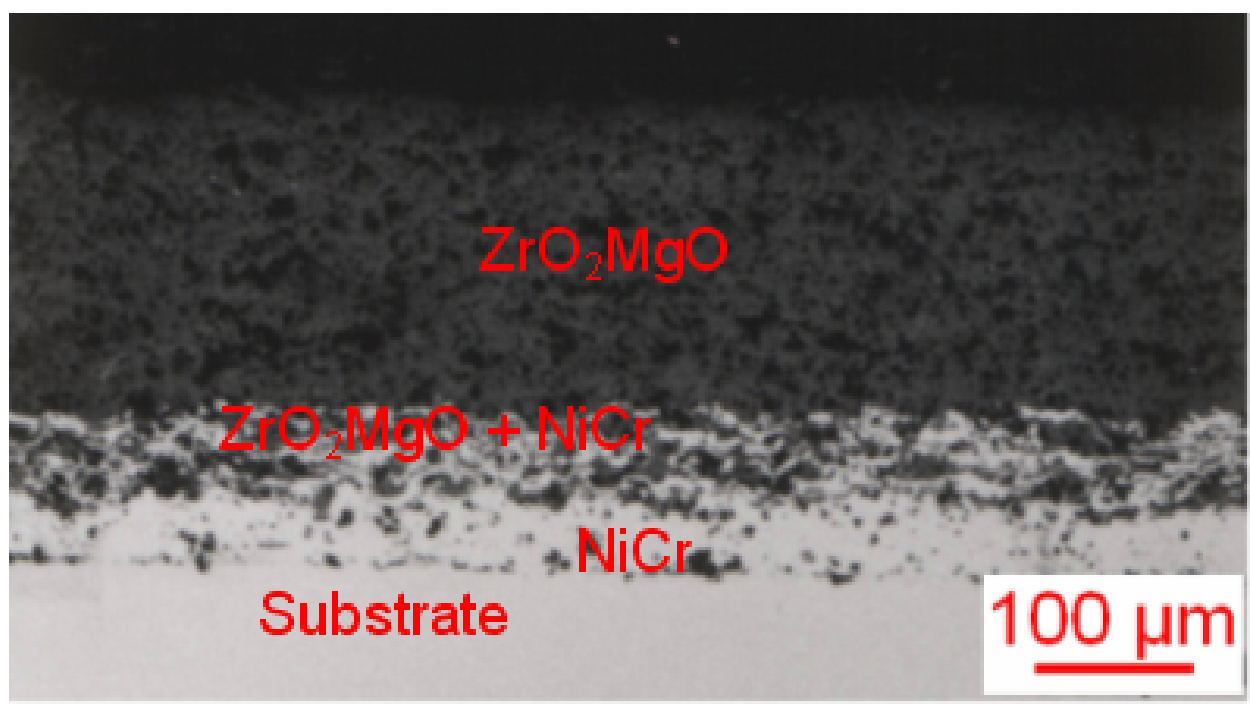

Figure 5 - Microstructure of the triple layer of $\mathrm{ZrO}_{2} \mathrm{MgO} / \mathrm{MgZrO}_{3} \mathrm{NiCr} / \mathrm{NiCr}$ coatings Slika 5 - Mikrotvrdoća troslojne prevlake $\mathrm{ZrO}_{2} \mathrm{MgO} / \mathrm{MgZrO}_{3} \mathrm{NiCr} / \mathrm{NiCr}$

Puc. 5 - Микротвердость трехслойного покрытия $\mathrm{ZrO}_{2} \mathrm{MgO} / \mathrm{MgZrO}{ }_{3} \mathrm{NiCr} / \mathrm{NiCr}$

In the layers of deposited coatings, there were no unmelted powder particles observed, which indicates that the powders were deposited with the optimal deposition parameters. The analysis of the photomicrographs showed that in the layers of bonding coatings $43 \mathrm{~F}-\mathrm{NS}(\mathrm{NI} 20 \% \mathrm{Cr})$ there were micro pores with an average share of $2.6 \%$. The share of micro pores in the layers of cermet coatings $303 \mathrm{NS}-1\left(\mathrm{MgZrO}_{3} 35 \% \mathrm{NiCr}\right)$ was $7 \%$, and the layers of ceramic coatings $210 \mathrm{NS}-1\left(\mathrm{ZrO}_{2} 24 \% \mathrm{MgO}\right)$ had the content of micro pores of $12 \%$.

The microstructure of the $\mathrm{NI} 20 \% \mathrm{Cr}$ bonding coating is lamellar. The coating base is a solid solution of chromium in nickel $y-\mathrm{Ni}(\mathrm{Cr})$. Between the lamellas of the solid solution in the coating layers there are light gray oxides: $\mathrm{NiO}, \mathrm{NiCr}_{2} \mathrm{O}_{4}, \mathrm{Cr}_{2} \mathrm{O}_{3}$ and $\mathrm{CrO}_{3}$ (Nicoll, 1984), (Mrdak, 2015, pp.32-55) due to oxidation of powder particles in plasma during the process of coating formation. In most cases, the oxide of chromium $\mathrm{Cr}_{2} \mathrm{O}_{3}$ is present and, in rare cases, oxide $\mathrm{CrO}_{3}$, formed in a thin layer on the surface of NiCr lamellae (Brossard, et al., 2010, pp.1608-1615). In the middle cermet inter-layer, there are clearly visible light gray lamellae of the bonding coating, evenly distributed between ceramic lamellae in dark gray. The top ceramic layer is uniformly deposited on the cermet layer in which black micro pores can be seen. 


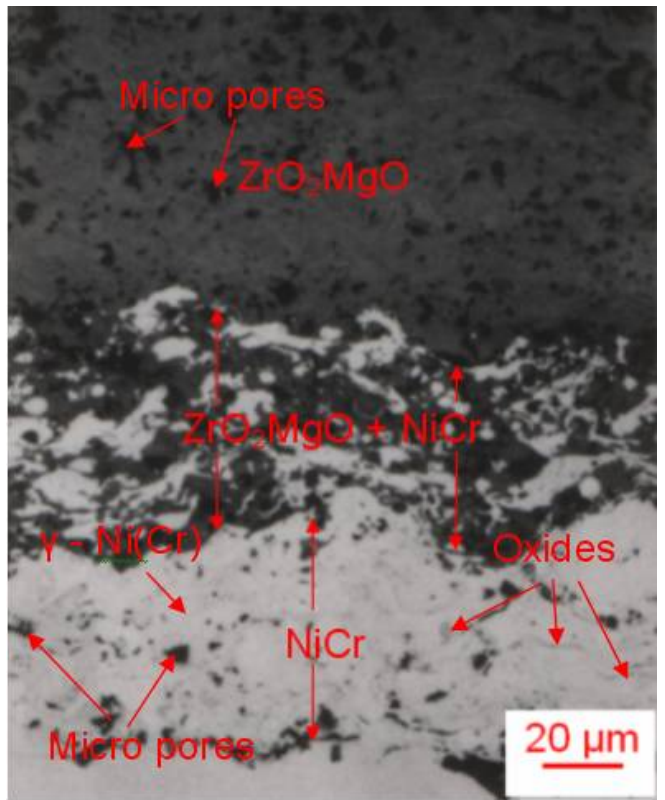

Figure 6 - Microstructure of the triple layer of $\mathrm{ZrO}_{2} \mathrm{MgO} / \mathrm{MgZrO}{ }_{3} \mathrm{NiCr} / \mathrm{NiCr}$ coatings Slika 6 - Mikrotvrdoća troslojne prevlake $\mathrm{ZrO}_{2} \mathrm{MgO} / \mathrm{MgZrO}_{3} \mathrm{NiCr} / \mathrm{NiCr}$

Puc. 6 - Микротвердость трехслойного покрытия $\mathrm{ZrO}_{2} \mathrm{MgO} / \mathrm{MgZrO}{ }_{3} \mathrm{NiCr} / \mathrm{NiCr}$

Figure 7 shows a SEM photomicrograph of the surface of a $\mathrm{ZrO}_{2} \mathrm{MgO}$ molten particle. The SEM analysis of the morphology of the surface of the deposited ceramic $\mathrm{ZrO}_{2} \mathrm{MgO}$ powder particle shows a complete melting and casting of ceramic particles on the previously deposited ceramic layer.

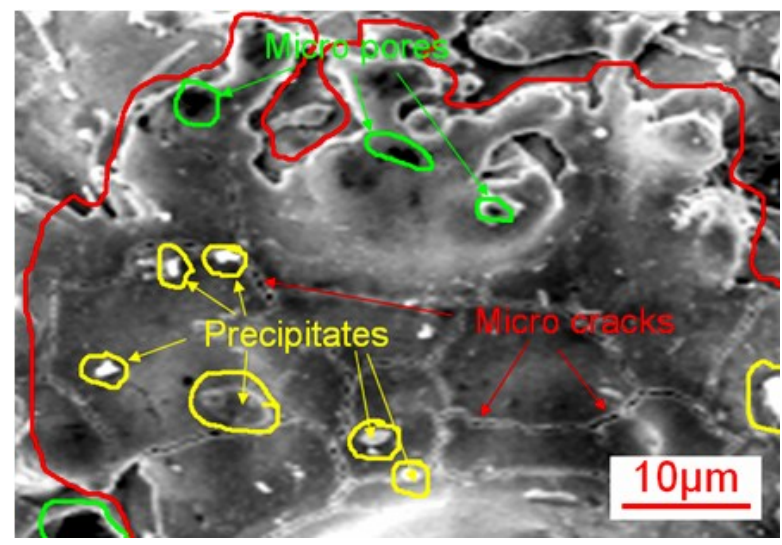

Figure 7 - (SEM) Morphology of the $\mathrm{ZrO}_{2} \mathrm{MgO}$ coating surface

Slika 7 - (SEM) Morfologija površine $\mathrm{ZrO}_{2} \mathrm{MgO}$ prevlake

Puc. 7 - Морфология поверхности $\mathrm{ZrO}_{2} \mathrm{MgO}$ покрытия 
The surface of the molten $\mathrm{ZrO}_{2} \mathrm{MgO}$ powder particle was circled with a red line on the SEM micrograph. The molten powder particle formed an almost circular shape in the collision with the surface of the previously deposited layer. The surface of the particle shows a fine net of microcracks which cannot be avoided and which always occurs in the deposition process (Guo, et al., 2011, pp.161-174).

Microcracks are formed during the cooling of molten particles to the coating temperature. The inner coating layers, which have a higher temperature compared to that of the coating surface, are exposed to tensile stress and are opposed to the shrinkage of the particles on the coating surface. On the other hand, the particles on the coating surface while cooling and shrinking during solidification, are exposed to compression stresses. Microcracks on the particle surface are caused by tensile stresses of deposited layers which are always higher than compression stresses of the particles while cooling Guo, et al., 2011, pp.161-174), (Mrdak, et al. 2013, pp.559-567), (Mrdak, 2013, pp.426432), (Mrdak, et al., 2015, pp.337-343). In the microstructure, there are fine precipitates of irregular shapes with a size up to $5 \mu \mathrm{m}$, circled in yellow. On the SEM micrograph, micro pores of irregular shapes in black with a size up to $5 \mu \mathrm{m}$ are clearly seen and circled in green.

\section{Conclusion}

This paper describes how the APS - atmospheric plasma spray process was used to produce a triple-layer system of thermal barrier coatings $\mathrm{TBC}-\mathrm{ZrO}_{2} 24 \% \mathrm{MgO} / \mathrm{MgZrO}_{3} 35 \% \mathrm{NiCr} / \mathrm{Ni} 20 \% \mathrm{Cr}$. The system of the deposited coatings consisted of the Ni80\% Cr bonding layer, the intermediary $\mathrm{MgZrO}_{3} 35 \% \mathrm{NiCr}$ inter-cermet layer and the top $\mathrm{ZrO}_{2} 24 \% \mathrm{MgO}$ ceramic layer. The coatings were deposited on the test $\mathrm{Al}$ alloy samples on the surfaces without roughening. The mechanical properties and the microstructures of the coating layers were analyzed in the deposited condition, which led to the following conclusions.

The triple-layer system of the thermal barrier coatings had good mechanical properties with the bonding layer microhardness values of $238-254 \mathrm{HV}_{0.3}$, the intermediary cermet layer microhardness values of 293$330 \mathrm{HV}_{0.3}$ and the top ceramic layer microhardness values of $478-519 \mathrm{HV}_{0.3}$. The microhardness values were within the limits prescribed by the Pratt\&Whitney standard. The bond strength of the deposited coatings on the non-roughened Al alloy samples had good values. The tensile bond strength was $31 \mathrm{MPa}$ for the bonding layer, $22 \mathrm{MPa}$ for the cermet coating and $17 \mathrm{MPa}$ for the ceramics. The bond strength of the triple-layer system of TBC coatings is $30 \mathrm{MPa}$. The analysis of the photomicrographs has shown that the average share of micro pores was $2.6 \%$ in the bonding 
layers, $7 \%$ in the cermet layers and $12 \%$ in the ceramic layers. The microstructure of the deposited coating layers is lamellar.

The coating base consists of a solid solution of chromium in nickel $\mathrm{y}$ - $\mathrm{Ni}(\mathrm{Cr})$. There are light gray $\mathrm{NiO}, \mathrm{NiCr}_{2} \mathrm{O}_{4}, \mathrm{Cr}_{2} \mathrm{O}_{3}$ and $\mathrm{CrO}_{3}$ oxides between the solid solution lamellae in the coating layers due to oxidation of powder particles in plasma during the coating formation process. In most cases, the oxide of chromium $\mathrm{Cr}_{2} \mathrm{O}_{3}$ is present and, in rare cases, oxide $\mathrm{CrO}_{3}$, formed in a thin layer on the surface of $\mathrm{NiCr}$ lamellae. The cermet inter-layer had a uniform distribution of bond coating lamellae between ceramic lamellae. The top ceramic layer is uniformly deposited on the cermet layer without the presence of unmelted particles.

The triple-layer system of thermal barrier coatings - $\mathrm{ZrO}_{2} 24 \% \mathrm{MgO} /$ $\mathrm{MgZrO}_{3} 35 \% \mathrm{NiCr} / \mathrm{Ni} 20 \% \mathrm{Cr}$, deposited on the Al alloy substrate as the thermal abrasive protection of the tail elevators of aircraft $\mathrm{J}-22$, proved to be reliable protection against the jet temperature and jet abrasive particles during firing of "Lightning" and "Thunder" rockets.

\section{Literature}

Boutz, M.M.R., Winnubst, A.J.A., Burggraaf, A.J., 1994, Yttria-ceria stabilized tetragonal zirconia polycrystals: Sintering, grain growth and grain boundary segregation, Journal of the European Ceramic Society, 13(2), pp.89-102.

Brossard, S., Munroe, P.R., Tran, A.T.T., Hyland, M.M., 2010, Study of the microstructure of $\mathrm{NiCr}$ splats plasma sprayed on to stainless steel substrates by TEM, Surface and Coatings Technology, 204(9-10), pp.1608-1615.

Celik E, Avci E, Yilmaz F., 1997, Evaluation of Interface Reactions in Thermal Barrier Ceramic Coatings, Surf. Coatings Technol., 97, pp.361-365.

Chevalier, J., Gremillard, L., Virkar, A.V., Clarke, D.R., 2009, The tetragonalmonoclinic transformation in zirconia: Lessons learned and future trends, Journal of the American Ceramic Society, 92(9), pp.1901-1920.

Demirkiran, A.S., Avci, E., 1999, Evaluation of functionally gradient coatings produced by plasma-spray technique.Surf. Coat. Technol. 116-119, pp.292-295.

Garvie ,R.C., 1970, Zirconium dioxide and some of its binary systems, in: Alper, A.M., (ed.), High-temperature oxides, Vol. 5-II, Academic Press, New York, pp.117-166.

Garvie, R.C., Hannink, R.H.J., and Pascoe, R.T., 1975, 'Ceramic steel?', Nature, 258, pp.703-704.

Guo, H., Yao, R. and Zhpu, L., 2011, in 'Thermal barrier coatings', (ed. Xu, H.and Guo, H.) Cambridge, Woodhead Publishing Limited, pp.161-174.

Johner,G., Schweitzer, K.K., 1984, Thermal barrier coatings for jet engine improvement, Thin Solid Films, 119(3), pp.301-315.

Li, C.-J. and Ohmori, A., 2002, Relationships Between the Microstructure and Properties of Thermally Sprayed Deposits, J. Thermal Spray Technol., 11(3), pp.365-374.

Material Product Data Sheet, 2012, Metco 43F-NS Nickel - 20\% Chromium Powders. Sulzer Metco. DSMTS-0109.0.

Material Product Data Sheet, 2012, Metco 303NS-1 Magnesium Zirconate - Nickel Chromium Cermet Blends. Sulzer Metco. DSMTS-0070.0. 
Metco 210NS-1 Magnesium Zirconate Powder, 2000, Sulzer Metco.Technical bulletin 10-289.

Miyamoto, Y., Kaysser, W.A., Rabin, B.H., Kawasaki, A., Ford, R.G., 1999, Functionally Graded Materials: Design, Processing and Applications,Kluwer Academic Publisher, Boston, p.100.

Mrdak, M., 2013, Ispitivanje mehaničkih i strukturnih osobina prevlaka otpornih na eroziju i visoke temperature, pp.426-432, SERBIATRIB '13, 13th International Conference on Tribology, Serbia, Kragujevac, 15-17.

Mrdak, M., Vencl, A., Nedeljkovic, B., Stanković, M., 2013, Influence of plasma spraying parameters on properties of the thermal barrier coatings, Materials Science and Technology, 29(5), pp.559-567.

Mrdak, M., Rakin, M., Medjo, B., Bajić, N., 2015, Experimental Study of Insulating Properties and Behaviour of Thermal Barrier Coating Systems in Thermo Cyclic Conditions, Materials \& Design, 67, pp.337-343.

Mrdak, M., 2015, Investigation of the influence of plasma spray sealing coatings on the effect of sealing the TV2-117A turbojet engine compressor, Vojnotehnički glasnik/MilitaryTechnical Courier, 63(1), pp.32-55.

Nicoll, A.R., 1984, The environment - high temperature oxidation and hot corrosion, $\mathrm{u}$ : CEI Course on High Temperature Materials and Coatings, Finland.

Turbojet Engine - Standard Practices Manual (PN 582005), 2002, Pratt \& Whitney, East Hartford, USA.

ХАРАКТЕРИСТИКИ ТРЕХСЛОЙНЫХ ТЕРМОБАРЬЕРНЫХ ПОКРЫТИЙ $\mathrm{ZrO}_{2} \mathrm{MgO} / \mathrm{MgZrO} \mathrm{NiCr} / \mathrm{NiCr}$, HAHECEHНЫХ ВОЗДУШНО-ПЛАЗМЕННЫМ НАПЫЛЕНИЕМ

Михаило Р. Мрдак

Центр исследований и развития А.О. «ИМТЕЛ коммуникации», Белград, Республика Сербия

ОБЛАСТЬ: химические технологии

ВИД СТАТЬИ: оригинальная научная статья

ЯЗЫК СТАТЬИ: английский

\section{Резюме:}

В данной статье представлены результаты испытаний термобарьерных покрытий ТБС $\mathrm{ZrO}_{2} \mathrm{MgO} / \mathrm{MgZrO}_{3} \mathrm{NiCr} / \mathrm{NiCr}$, нанесенных воздушно-плазменным напылением при атмосферном давлении на субстраты сплавов Al.

Испытания проводились с целью получения структурных и механических характеристик слоев, обеспечивающих качественную и абразивную защиту задних крыльев самолета J-22 при выпуске ракет, а также от грома и молний. Нанесено напыление трех типов порошков на субстраты сплавов Al, толщиной 0,6мм. 
В данном исследовании представлен метод применения трехслойного ТБС покрытия, которое обладает лучшими защитными свойствами, когда речь идет о термоизоляции и защите от абразивного износа задних крыльев самолета.

Анализ механических характеристик покрытия проведен на основании испытаний микротвердости методом $H V_{0.3}$ u прочности соединений методом растяжения. Структура слоев испытана методом оптической микроскопии, а поверхность $\mathrm{ZrO}_{2} \mathrm{MgO}$ испытана методом электронной микрографии (SEM).

Испытания теплоизоляционных ТБС слоев и сопротивления абразивному износу были проведены в аэродинамической трубе Военно-технического института Жарково. На основании полученных характеристик поверхности слоев и моделирования выпуска ракет, можно утверждать, что трехслойные системы ТБС являются надежным способом покрытия.

Ключевые слова: субстраты, защита, характеристика, слои, покрытие, барьер, сплавы.

\section{SVOJSTVA TROSLOJNE TERMOBARIJERNE PREVLAKE $\mathrm{ZrO}_{2} \mathrm{MgO} /$ $\mathrm{MgZrO}_{3} \mathrm{NiCr} / \mathrm{NiCr}$ DEPONOVANE ATMOSFERSKIM PLAZMA SPREJ PROCESOM}

Mihailo R. Mrdak

Istraživački i razvojni centar IMTEL Komunikacije a. d., Beograd,

Republka Srbija

OBLAST: hemijske tehnologije

VRSTA ČLANKA: originalni naučni članak

JEZIK ČLANKA: engleski

Sažetak:

U radu su prikazani rezultati ispitivanja termobarijernih slojeva $\mathrm{TBC}-\mathrm{ZrO}_{2} \mathrm{MgO} / \mathrm{MgZrO}_{3} \mathrm{NiCr} / \mathrm{NiCr}$ koji su deponovani plazma sprej procesom na atmosferskom pritisku na substratima od legure Al. Radi dobijanja strukturnih i mehaničkih osobina slojeva, koji će obezbediti dobru toplotnu i abrazivnu zaštitu zadnjim krilima aviona J-22 pri ispaljivanju raketa munje i groma, izvršena je depozicija tri tipa praha na substratima od legure Al debljine 0,6 $\mathrm{mm}$. Ova studija opisuje postupak korišćenja troslojne TBC prevlake kao izbor dobre kombinacije od mnogo raspoloživih mogućnosti, koja predstavlja kompromis između toplotne zaštite i otpornosti na abraziju za zaštitu zadnjih krila aviona. Studija se, uglavnom, zasniva na eksperimentalnom pristupu. Procena mehaničkih osobina slojeva urađena je ispitivanjem mikrotvrdoće me- 
todom $H V_{0.3}$ i čvrstoće spoja ispitivanjem na zatezanje. Struktura slojeva ispitana je metodom svetlosne mikroskopije i površina $\mathrm{ZrO}_{2} \mathrm{MgO}$ keramičkih slojeva metodom skenirajuće elektronske mikroskopije (SEM). Toplotna zaštita TBC slojeva i otpornost na abraziju ispitana je u tunelu Vojnotehničkog instituta iz Žarkova. Na osnovu dobijenih karakteristika površinskih slojeva i simuliranja ispaljivanja rakete, troslojni sistem TBC prevlake pokazao se pouzdanim.

Uvod

TBC termobarijerne plazma sprej prevlake uveliko se koriste kao zaštita delova turbomlaznih motora i za druge delove motora izložene visokim temperaturama, oksidaciji, gasnoj koroziji i eroziji čestica. Plazmom deponovane TBC keramičke prevlake dobro su rešenje za toplotnu zaštitu delova dizel motora, kao što su klipovi, ventili, itd. (Çelik, et al., 1997, pp.361-365), (Demirkiran, Avci, 1999, pp.292-295), (Miyamoto, et al., 1999, p.100). Izbor oksida $\mathrm{ZrO}_{2}$ izvršen je zbog visoke čvrstoće i žilavosti loma u odnosu na druge okside i fizičkih karakteristika, kao što je toplotna provodljivost $\lambda \approx 1.7 \mathrm{~W} / \mathrm{mK}$, koeficijent termičke ekspanzije $\alpha \approx 9 \times 10^{-} 61 / \mathrm{K}$ i temperature topljenja $2710^{\circ} \mathrm{C}$ (Boutz, et al., 1994, pp.89-102), (Chevalier, et al., 2009, pp.1901-1920). Na atmosferskom pritisku postoje tri kristalografske faze: monoklinična, tetragonalna i kubna. Prilikom naizmeničnog zagrevanja i hlađenja dolazi do toplotnog zamora $\mathrm{ZrO}_{2}$ meterijala usled zapreminskih promena uzrokovanih faznom transformacijom. Kao posledica reverzibilne transformacije monoklinične faze u tetragonalnu u temperaturnom opsegu od $950^{\circ}$ do $1170^{\circ} \mathrm{C}$ uočen je nastanak mikropukotina koje se šire i pretvaraju u makropukotine (Garvie, et al., 1975, pp.703-704), (Garvie, 1970, pp.117-166). Zbog toga čisti $\mathrm{ZrO}_{2}$ nije pogodan za izradu TBC prevlaka. Radi smanjenja efekta tetragonalne transformacije u monokliničnu, čistom $\mathrm{ZrO}_{2}$ dodaju se drugi oksidi, kao što su: $\mathrm{MgO}, \mathrm{CaO}$, $\mathrm{Y}_{2} \mathrm{O}_{3}, \mathrm{CeO}_{2}, \mathrm{H}_{\mathrm{f}} \mathrm{O}_{2}$ i $\mathrm{In}_{2} \mathrm{O}_{3} . \mathrm{ZrO}_{2}$ sa dodatkom magnezijumoksida $\mathrm{MgO}$ često se koristi kao TBC zbog velikog koeficijenta linearnog širenja koji je $11 \times 10^{-6} 1 / \mathrm{K}$, koeficijenta toplotne provodljivosti $1,5 \mathrm{~W} / \mathrm{mK}$, velike otpornosti na toplotne cikluse, otpornosti na koroziju i lake izrade prevlake plazma sprej prskanjem. TBC prevlake sastoje se najmanje od dva sloja: spoljašnjeg, po pravilu debljeg sloja, sačinjenog od keramičkog materijala ili mešavine keramike i vatropostojanih metala, koji pre svega treba da obezbedi toplotnu izolaciju i otpornost na termošokove. Materijal keramičkog sloja koji se nalazi u direktnom kontaktu sa radnim fluidom ima pad temperature po preseku i do $400-500^{\circ} \mathrm{C}$ (Mrdak, et al., 2013, pp.559-567), (Mrdak, et al., 2015, pp.337-343). Da bi se smanjili naponi često se proizvode troslojni sistemi TBC prevlaka koji se sastoje od veznog sloja Ni20\%Cr, prelaznog kermet međusloja $\mathrm{MgZrO}_{3} 35 \% \mathrm{NiCr}$ i gornjeg keramičkog sloja $\mathrm{ZrO}_{2} 24 \% \mathrm{MgO}$. Ova studija 
opisuje postupak korišćenja troslojne TBC prevlake kao izbor dobre kombinacije, od mnogo raspoloživih mogućnosti, koja daje dobar kompromis između toplotne zaštite $i$ otpornosti na eroziju substrata od legure Al za zaštitu zadnjih krila aviona J-22. Studija se uglavnom zasnivala na eksperimentalnom pristupu. Svojstva deponovanih materijala su generalno funkcije njihovih mikrostruktura.

$U$ ovom radu ispitan je troslojni sistem TBC prevlaka $\mathrm{ZrO}_{2} \mathrm{MgO} / \mathrm{MgZrO}_{3} \mathrm{NiCr} / \mathrm{NiCr}$ koji je deponovan atmosferskim plazma sprej (APS) postupkom na substratima od legure Al, koji služe kao termoabrazivna barijera zadnjim krilima aviona J-22. Cilj rada je bio da se proizvedu TBC prevlake strukturnih i mehaničkih osobina slojeva, koji će obezbediti dobru toplotnu i abrazivnu zaštitu zadnjim krilima aviona pri ispaljivanju raketa munje i groma. Ispitane su mikrotvrdoće i zatezne čvrstoće spoja trojnih sistema TBC prevlaka i mikrostrukture slojeva. Na osnovu dobijenih karakteristika TBC slojeva i simuliranja ispaljivanja rakete troslojni sistem TBC prevlake pokazao se pouzdanim.

Materijali i eksperimentalni detalji

Materijal na kojem su deponovani slojevi troslojne TBC $\mathrm{ZrO}_{2} \mathrm{MgO} / \mathrm{MgZrO}_{3} \mathrm{NiCr} / \mathrm{NiCr}$ prevlake bio je od legure aluminijuma ENAW-AIMg1(C)(ENAW-5005A). Za izradu slojeva gornje keramičke prevlake upotrebljen je prah $\mathrm{ZrO}_{2} 24 \% \mathrm{MgO}$ firme Sulzer Metco sa oznakom Metco 210NS-1. Prah je proizveden metodom livenja u blokove i naknadnim mlevenjem blokova na određenu granulaciju. Temperatura topljenja praha je $2140^{\circ} \mathrm{C}$. Za eksperiment se koristio prah koji je imao raspon granulata od 10 do $53 \mu \mathrm{m}$, a čestice praha su nepravilnog uglastog oblika (Metco 210NS-1 Magnesium Zirconate Powder, 2000. Sulzer Metco.Technical bulletin 10-289). Za izradu srednjih slojeva TBC prevlake upotrebljen je kermet prah $\mathrm{MgZrO}_{3} 35 \% \mathrm{NiCr}$, firme Sulzer Metco, koji nosi oznaku Metco 303 NS1. Prah je mehanička mešavina praha $\mathrm{ZrO}_{2} \mathrm{MgO} i \mathrm{NiCr}$ u odnosu $35 \%(80 \mathrm{Ni20} \% \mathrm{Cr})+65 \%\left(\mathrm{ZrO}_{2} 24 \% \mathrm{MgO}\right)$. Za eksperiment se koristio prah koji je imao raspon granulata od 11 do 90 $\mathrm{mm}$ (Material Product Data Sheet, 2012. Metco 303NS-1 Magnesium Zirconate - Nickel Chromium Cermet Blends. Sulzer Metco. DSMTS-0070.0). Za izradu donjeg veznog sloja koristio se prah oznake Metco 43F-NS, koji je legura nikla i hroma Ni20\% Cr. Temperatura topljenja praha je $1400^{\circ} \mathrm{C}$. Za eksperiment se koristio prah koji je imao raspon granulata od 10 do 63 $\mu m$ (Material Product Data Sheet, 2012. Metco 43F-NS Nickel - 20\% Chromium Powders, Sulzer Metco. DSMTS-0109.0).

Ispitivanje mehaničkih karakteristika slojeva TBC prevlake $\mathrm{ZrO}_{2} \mathrm{MgO} / \mathrm{MgZrO}_{3} \mathrm{NiCr} / \mathrm{NiCr}$ rađeno je prema standardu Pratt \& Whitney (Turbojet Engine - Standard Practices Manual (PN 582005), 2002. Pratt \& Whitney, East Hartford, USA). Osnove na kojima su deponova- 
ni slojevi prevlake za ispitivanje mikrotvrdoće i za procenu mikrostrukture $u$ deponovanom stanju izrađene su od legure aluminijuma ENAW-AIMg1(C)(ENAW-5005A) dimenzija 70x20x1,5 mm. Osnove za ispitivanje čvrstoće spoja takođe su izrađene od legure aluminijuma ENAW-AIMg1(C)(ENAW-5005A), dimenzija Ø25x50 mm. Ispitivanje mikrotvrdoće slojeva rađeno je metodom $\mathrm{HV}_{0.3}$ i čvrstoće spoja ispitivanjem na zatezanje. Merenje mikrotvrdoće izvršeno je u pravcu duž lamela. Izvršeno je pet očitavanja vrednosti mikrotvrdoće slojeva u sredini i na krajevima uzoraka od kojih su odbačene dve krajnje vrednosti. Od tri preostale vrednosti prikazane su minimalne i maksimalne vrednosti. Ispitivanje čvrstoće spoja rađeno je na sobnoj temperaturi sa brzinom zatezanja $1 \mathrm{~cm} / 60 \mathrm{~s}$. Izvršeno je ispitivanje čvrstoće spoja pojedinačno svake prevlake 43F-NS(80Ni20\%Cr), 303NS$1\left(\mathrm{MgZrO}_{3} 35 \% \mathrm{NiCr}\right)$ i $210 \mathrm{NS}-\left(\mathrm{ZrO}_{2} 24 \% \mathrm{MgO}\right)$, kao i ispitivanje čvrstoće spoja trojnog sistema $\mathrm{TBC}-\mathrm{ZrO}_{2} \mathrm{MgO} / \mathrm{MgZrO}_{3} \mathrm{NiCr} / \mathrm{NiCr}$ prevlaka. Ispitano je po pet epruveta za sve tipove prevlaka od kojih su odbačene dve krajnje vrednosti. Od tri preostale vrednosti prikazana je srednja vrednost čvrstoće spoja. Morfologija čestica praha $\mathrm{ZrO}_{2} 24 \% \mathrm{MgO}$ i površina deponovane prevlake urađena je skening elektronskom mikroskopijom (SEM). Mikrostruktura deponovanih slojeva ispitana je na optičkom mikroskopu (OM). Analiza udela mikropora u slojevima prevlake urađena je obradom 5 fotografija na uveličanju 200x. Preko paus papira mikropore su označene i osenčene, a njihova ukupna površina računala se na ukupnu površinu mikrofotografije. U radu je prikazana srednja vrednost udela mikropora u slojevima TBC prevlake.

Depozicija prahova urađena je sa atmosferski plazma sprej sistemom, firme Plasmadyne, i plazma pištoljem SG-100, sa kontrolisanim plazma sprej parametrima. Plazma pištolj SG-100 sastojao se od katode tipa K 1083A-129, anode tipa A 1083-165 i gas injektora tipa GI 1083A-113. Kao lučni gas koristio se Ar u kombinaciji sa He $i$ snaga napajanja do $40 \mathrm{KW}$. Pre procesa deponovanja površine ispitnih uzoraka i površina substrata termoabrazivne barijere za zadnja krila aviona nisu hrapavljene, zbog male debljine substrata od 0,6mm. Vezni slojevi su deponovani sa debljinom od 60 do $80 \mu \mathrm{m}$, kermet slojevi sa debljinom od 40 do $60 \mu \mathrm{m}$ i gornji keramički sloj sa debljinom od 280 do $300 \mu \mathrm{m}$.

\section{Rezultati i diskusija}

Vezna metalna prevlaka 43F-NS(Ni20\%Cr) imala je najmanje vrednosti mikrotvrdoće od 238 do $254 \mathrm{HV}_{0.3}$, koje su u granicama vrednosti koje propisuje proizvođač praha i standard (Material Product Data Sheet, 2012. Metco 43F-NS Nickel - 20\% Chromium Powders. Sulzer Metco. DSMTS-0109.0), (Turbojet Engine-Standard Practices Manual (PN 582005) 2002. Pratt \& Whitney, East Hartford, USA). Izmerene 
vrednosti mikrotvrdoće veznih slojeva ukazuju na to da je udeo mikropora u propisanim granicama, što je potvrdila analiza udela mikropora. Zbog sadržaja keramike slojevi kermet prevlake 303NS$1\left(\mathrm{MgZrO}_{3} 35 \% \mathrm{NiCr}\right)$ imali su veće vrednosti mikrotvrdoće, koje su bile u rasponu 293-330HV ${ }_{0.3}$ i u skladu sa standardom Pratt \& Whitney (Turbojet Engine - Standard Practices Manual (PN 582005)(2002), Pratt \& Whitney, East Hartford, USA). Slojevi keramičke prevlake Metco 210NS-1 $\left(\mathrm{ZrO}_{2} 24 \% \mathrm{MgO}\right)$ imali su najveće vrednosti mikrotvrdoće od 478 do $519 H V_{0.3}$ koje su karakteristične za ovaj tip prevlake. Ovi slojevi su pokazali najveći udeo mikropora, jer keramičke čestice ostvaruju slabiji međulamelarni kontakt u odnosu na metalne čestice. Zatezna čvrstoća spoja prevlaka bila je u direktnoj vezi sa tipom praha. Najveće vtrenosti čvrstoće spoja od $31 \mathrm{MPa}$ imali su metalni vezni slojevi prevlake 43F- NS (Ni20\%Cr). Slojevi kermet prevlake 303NS$1\left(\mathrm{MgZrO}_{3} 35 \% \mathrm{NiCr}\right.$ ) imali su zateznu čvrstoću spoja od $22 \mathrm{MPa}$, a najmanju vrednost od $17 \mathrm{MPa}$ imali su keramički slojevi Metco 210NS-1 $\left(\mathrm{ZrO}_{2} 24 \% \mathrm{MgO}\right)$. Za sve prevlake vrednosti čvrstoće spoja bile su dobre, jer su se prevlake deponovale na neohrapavljenim substratima od legure Al koji umanjuju zateznu čvrstoću spoja u odnosu na hrapavljene substrate na bazi legura Fe ili Ni. Srednja vrednost zatezne čvrstoće sistema $\mathrm{TBC}-\mathrm{ZrO}_{2} \mathrm{MgO} / \mathrm{MgZrO}{ }_{3} \mathrm{NiCr} / \mathrm{NiCr}$ prevlaka bila je $30 \mathrm{MPa}$.

Na uzorcima se jasno uočavaju granice međuspoja između slojeva vezne prevlake $i$ substrata, vezne prevlake $i$ kermet prevlake $i$ kermet prevlake i keramičke prevlake. Međugranica između substrata i slojeva vezne prevlake je izuzetno čista, ukazujući na dobru vezu slojeva prevlake sa substratom. Na interfejsu između substrata i slojeva vezne prevlake nisu prisutni defekti kao što je diskontinuitet deponovanih slojeva, mikropukotine, makropukotine, ljuštenje i odvajanje prevlake sa substrata. Generalno, slojevi su ravnomerno deponovani na podlogu. Duž interfejsa između substrata/vezna prevlaka, vezna prevlaka/ kermet prevlaka i kermet prevlaka/keramička prevlaka nisu prisutne mikropukotine i makropukotine. Veza između svih slojeva je dobra. U slojevima deponovanih prevlaka nisu uočene neistopljene čestice praha, ukazujući da su prahovi deponovani sa optimalnim parametrima depozicije. Analiza mikrofotografija je pokazala da su u slojevima vezne prevlake $43 \mathrm{~F}-\mathrm{NS}(\mathrm{Ni} 20 \% \mathrm{Cr}$ ) prisutne mikropore sa srednjim udeIom od 2,6\%. Udeo mikropora u slojevima kermet prevlake 303NS$1\left(\mathrm{MgZrO}_{3} 35 \% \mathrm{NiCr}\right)$ bio je $7 \%$, a u slojevima keramičke prevlake $210 \mathrm{NS}-1$ ( $\left.\mathrm{ZrO}_{2} 24 \% \mathrm{MgO}\right)$; sadržaj mikropora bio je $12 \%$. Analiza mikrofotografija je pokazala da su u slojevima vezne prevlake 43FNS(Ni20\%Cr) prisutne mikropore sa srednjim udelom od 2,6\%. Udeo mikropora u slojevima kermet prevlake $303 \mathrm{NS}-1\left(\mathrm{MgZrO}_{3} 35 \% \mathrm{NiCr}\right)$ bio je $7 \%$, a u slojevima keramičke prevlake $210 \mathrm{NS}-1$ ( $\left.\mathrm{ZrO}_{2} 24 \% \mathrm{MgO}\right)$ sadržaj mikropora iznosio je 12\%. SEM analiza morfologije površine deponovane keramičke čestice praha $\mathrm{ZrO}_{2} \mathrm{MgO}$ pokazuje potpuno toplje- 
nje i razlivanje keramičkih čestica na prethodno deponovani keramički sloj. Istopljena čestica praha je u sudaru sa površinom prethodno deponovanog sloja formirala približno kružan oblik. Na površini čestice vidi se fina mreža mikropukotina koja se ne može izbeći i uvek se javlja u procesu depozicije (Guo, et al., 2011, pp.161-174). Mikropukotine se formiraju za vreme hlađenja istopljene čestice do temperature prevlake. Unutrašnji slojevi prevlake koji imaju veću temperaturu u odnosu na površinu prevlake izloženi su naponima na istezanje i suprotstavljaju se skupljanju čestice na površini prevlake. S druge strane, čestica na površini prevlake koja se hladi i skuplja tokom očvršćavanja izložena je naponima na sabijanje. Naponi na istezanje deponovanih slojeva koji su uvek veći od napona na sabijanje čestice koja se hladi na površini prevlake uzrokuju stvaranje mikropukotina na površini čestice (Guo, et al., 2011, pp.161-174), (Mrdak, et al. 2013b, pp.559-567), (Mrdak, 2013a, pp.426-432), (Mrdak, et al., 2015a, pp.337-343). U mikrostrukturi su prisutni fini precipitati nepravilnog oblika veličine do 5 $\mu m$, koji su zaokruženi žutom bojom. Na SEM mikrofotografiji jasno se vide mikropore nepravilnog oblika crne boje, veličine do $5 \mu \mathrm{m}$, zaokružene zelenom bojom.

Zaključak

$U$ ovom radu je atmosferskim plazma sprej procesom (APS) proizveden troslojni sistem termobarijernih prevlaka $\mathrm{TBC}-\mathrm{ZrO}_{2} 24 \% \mathrm{MgO} / \mathrm{MgZrO}_{3} 35 \% \mathrm{NiCr} / \mathrm{Ni} 20 \% \mathrm{Cr}$. Sistem deponovanih prevlaka sastojao se od veznog sloja Ni80\%Cr, srednjeg prelaznog međukermet sloja $\mathrm{MgZrO}_{3} 35 \% \mathrm{NiCr}$ i gornjeg keramičkog sloja $\mathrm{ZrO}_{2}$ $24 \% M g O$. Prevlake su deponovane na ispitnim uzorcima od legure Al na površinama bez hrapavljenja. Analizirane su mehaničke karakteristike i mikrostrukture slojeva prevlaka u deponovanom stanju, na osnovu čega se došlo do određenih zaključaka.

Troslojni sistem termobarijernih prevlaka imao je dobre mehaničke karakteristike sa vrednostima mikrotvrdoće veznog sloja od 238 do $254 H V_{0.3}$, prelaznog kermet sloja od 293 do $330 H V_{0.3}$ i gornjeg keramičkog sloja od 478 do $519 H V_{0.3}$. Vrednosti mikrotvrdoće bile su u granicama koje propisuje standard Pratt \& Whitney. Čvrstoće spoja deponovanih prevlaka na neohrapavljenim uzorcima od legure Al imale su dobre vrednosti. Za vezni sloj zatezna čvrstoća spoja bila je $31 \mathrm{MPa}$, za kermet prevlaku $22 \mathrm{MPa}$, a za keramiku $17 \mathrm{MPa}$. Čvrstoća spoja troslojnog sistema TBC prevlaka bila je $30 \mathrm{MPa}$. Analiza mikrofotografija je pokazala da je srednji udeo mikropora u veznim slojevima bio 2,6\%, u kermet slojevima 7\% i u keramičkim 12\%. Mikrostruktura deponovanih slojeva prevlaka je lamelarna. Osnova prevlake sastoji se od čvrstog rastvora hroma u niklu y - Ni(Cr). Između lamela čvrstog rastvora u slojevima prevlake prisutni su svetlosivi oksidi tipa NiO, Ni- 
$\mathrm{Cr}_{2} \mathrm{O}_{4}, \mathrm{Cr}_{2} \mathrm{O}_{3}$ i $\mathrm{CrO}_{3}$, usled oksidacije čestica praha u plazmi tokom procesa izrade prevlake. U većini slučajeva prisutan je oksid hroma $\mathrm{Cr}_{2} \mathrm{O}_{3}$, a ređe oksid $\mathrm{CrO}_{3}$, koji se formiraju u vidu tankog sloja na površini NiCr lamela. Kermet međusloj imao je ravnomernu raspodelu lamela vezne prevlake između keramičkih lamela. Gornji keramički sloj ravnomerno je deponovan na kermet sloju bez prisustva neistopljenih čestica.

Troslojni sistem termobarijernih prevlaka $\mathrm{ZrO}_{2} 24 \% \mathrm{MgO} / \mathrm{MgZrO}_{3} 35 \% \mathrm{NiCr} / \mathrm{Ni20} \% \mathrm{Cr}$ deponovan na substratu od legure Al kao termoabrazivne zaštite zadnjih krila aviona J-22 pokazao se kao pouzdana zaštita od temperaturnog mlaza $i$ abrazivnih čestica raketa munje i groma.

Ključne reči: supstrati, zaštita, svojstvo, slojevi, prevlake, barijere, legure.

Datum prijema članka / Дата получения работы / Paper received on: 28. 11. 2015.

Datum dostavljanja ispravki rukopisa / Дата получения исправленной версии работы / Manuscript corrections submitted on: 10. 12. 2015.

Datum konačnog prihvatanja članka za objavljivanje / Дата окончательного согласования работы / Paper accepted for publishing on: 12. 12. 2015.

(C) 2016 Autor. Objavio Vojnotehnički glasnik / Military Technical Courier (www.vtg.mod.gov.rs, втг.мо.упр.срб). Ovo je članak otvorenog pristupa i distribuira se u skladu sa Creative Commons licencom (http://creativecommons.org/licenses/by/3.0/rs/).

(c) 2016 Автор. Опубликовано в "Военно-технический вестник / Vojnotehnički glasnik / Military Technical Courier" (www.vtg.mod.gov.rs, втг.мо.упр.срб). Данная статья в открытом доступе и распространяется в соответствии с лицензией "Creative Commons" (http://creativecommons.org/licenses/by/3.0/rs/).

(c) 2016 The Author. Published by Vojnotehnički glasnik / Military Technical Courier (www.vtg.mod.gov.rs, втг.мо.упр.срб). This article is an open access article distributed under the terms and conditions of the Creative Commons Attribution license (http://creativecommons.org/licenses/by/3.0/rs/).

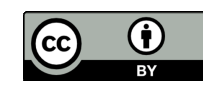

